\title{
Seroprevalensi Antibodi Newcastle Disease (ND) pada Itik di Desa Temuasri, Sempu, Banyuwangi
}

\author{
Seroprevalence of Newcastle Disease (ND) Antibodies on Ducks in Temuasri Village, \\ Sempu, Banyuwangi
}

\author{
Fachrur Rozi ${ }^{1 *}$, Jola Rahmahani ${ }^{2}$, Muhammad Thohawi Elziyad Purnama ${ }^{3}$, Iwan \\ Sahrial Hamid ${ }^{4}$, Aditya Yudhana ${ }^{5}$, Ratih Novita Praja ${ }^{2}$ \\ ${ }^{1}$ Mahasis wa, ${ }^{2}$ Departemen Mikrobiologi, ${ }^{3}$ Departemen Anatomi Veteriner, ${ }^{4}$ Departemen Kedokteran Das ar \\ Veteriner, ${ }^{5}$ Departemen Parasitologi Veteriner, \\ Fakultas Kedokteran Hewan, Universitas Airlangga, \\ Kampus C Mulyorejo, Surabaya, Jawa Timur, Indonesia, 60115 \\ *Corresponding author: fachrur.rozi-2015@fkh.unair.ac.id
}

\begin{abstract}
Abstrak
Tujuan penelitian ini untuk mendeteksi titer antibodi ND pada itik di Desa Temuasri Kecamatan Sempu Kabupaten Banyuwangi. Deteksi antibodi ND diperiksa dengan uji Hemaglutinasi (HA) dan Hambatan Hemaglutinasi (HI). Penelitian menggunakan desain penelitian non-eksperimental dengan metode survei deskriptif. Kegiatan penelitian ini mengambil 72 sampel darah itik di Desa Temuasri Kecamatan Sempu Kabupaten Banyuwangi dengan metode cross-sectional. Serum dipisahkan dari bekuan darah, kemudian serum dipindahkan ke dalam microtube. Sebelum melakukan uji HA dan uji HI, sampel harus diberi perlakuan dengan menggunakan Red Blood Cell (RBC) $100 \%$ dan diinaktifasi ke dalam waterbath pada $56^{\circ} \mathrm{C}$ selama 30 menit, tujuannya untuk menghilangkan aglutinin non-spesifik dan menonaktifkan reaksi non-spesifik serum. Uji $\mathrm{HI}$ positif ketika menunjukkan pengendapan eritrosit berbentuk titik pada dasar sumuran micoplate. Hasil penelitian ini menunjukkan $20(27.77 \%)$ dari 72 sampel positif ND.
\end{abstract}

Kata kunci: itik, Newcastle Disease, seroprevalensi

Abstract

The aim of this study was to detect ND antibody titers on ducks in Temuasri village Sempu subdistrict, Banyuwangi District. Detection of ND antibody was examined by Hemagglutination (HA) and Hemagglutination Inhibition (HI) test. This research used a non-experimental design with descriptive survey method. It took 72 samples of duck's blood in Temuasri village Sempu subdistrict, Banyuwangi District by cross-sectional method. The serum was separated from the blood clot, then it transferred into the microtube. Before carrying out the HA test and HI test, the samples must be treated by $100 \%$ of chicken red blood cell $(R B C)$ and inactivated into the waterbath at $56^{\circ} \mathrm{C}$ for 30 minutes, so that it can eliminate the non-specific aglutinin and inactivate non-specific reaction of serum. HI test positive showed the deposition of point-shaped erythrocytes on the base of the micoplate wells. The results of this study showed 20 (27.77\%) of 72 positive ND.

Key words: duck, Newcastle Disease, seroprevalence

Received: 29 Mei 2019

Revised: 20 Juni 2019

Accepted: 6 Juli 2019

\section{PENDAHULUAN}

Newcastle Disease (ND) atau penyakit tetelo merupakan penyakit unggas yang sangat menular dan merugikan ekonomi di peternakan unggas. Tahun 2002-2003, Amerika Serikat mengalami wabah ND dengan tingkat mortalitas lebih dari 3 juta ekor unggas dengan kerugian ekonomi sebesar 5 miliar dolar Amerika (CFSPH., 2008). Penyakit ND pertama kali ditemukan Kraneveld pada tahun 1926 di Jakarta, yang merupakan penyakit bersifat endemik di Indonesia dan hampir dapat ditemukan di berbagai daerah (Darminto dan Ronohardjo., 1996).

Berdasarkan virulensinya, virus ND dikelompokkan menjadi tiga, yaitu: lentogenik, 
strain virus yang kurang virulen; mesogenik, strain virus yang virulensi sedang; velogenik, strain virus yang virulensi ganas. Strain velogenik dibedakan lagi menjadi bentuk neutrofik dan viserotrofik, yang mana neutrofik menimbulkan gejala gangguan saraf dan kelainan pada sistem pernapasan, dan viserotrofik menimbulkan gejala yang ditandai dengan kelainan pada sistem pencernaan (Aldous dan Alexander, 2001).

ND mempengaruhi banyak spesies burung dengan rata-rata morbiditas dan mortalitas beragam dengan kemunculan gejala klinis berubah-ubah dari spesies ke spesies, di peternakan ayam ataupun itik kasus ND sangat tinggi tingkat morbiditas dan mortalitasnya mendekati $100 \%$ pada kelompok ternak yang tidak divaksinasi. Resisten terhadap infeksi ND biasanya pada itik, unggas air, burung nuri/beo, dan angsa mungkin tidak menunjukkan gejala klinis (Miller et al., 2010). Menurut Alexander dan Senne (2008) negara yang terbebas dari virus ND perlu mengeluarkan dana untuk pengujian berkala dalam mempertahankan status bebas terhadap ND untuk mendukung izin perdagangan, sedangkan pada negara berkembang yang endemik dengan ND dapat menimbulkan kerugian menurunnya kesehatan, sosial ekonomi masyarakat, serta kualitas dan kuantitas telur dan daging untuk konsumsi.

Itik merupakan komoditas peternakan yang sangat potensial dan dapat diandalkan untuk memperbaiki taraf hidup masyarakat. Hal ini dapat dilihat dari meningkatnya konsumsi daging dan telur itik dari tahun 2006 konsumsi daging mencapai $341.389 \mathrm{~kg}$ dan konsumsi telur mencapai $4.763 .7333 \mathrm{~kg}$ (BPS, 2006), tahun 2008 konsumsi daging $7.010 .928 \mathrm{~kg}$ dan konsumsi telur 4.782.797 kg (BPS., 2008), dan tahun 2010 konsumsi daging mencapai $7.716 .573 \mathrm{~kg}$ dan konsumsi telur mencapai 5.274.335 kg (BPS., 2010). Cara pemeliharaan itik di Kecamatan Sempu Kabupaten Banyuwangi kebanyakan dengan sistem ekstensif atau semi intensif, yaitu pemeliharaan dengan cara menggembalakan itik secara berpindah-pindah dari satu hamparan sawah pasca panen ke hamparan sawah pasca panen lainnya (Dinas Pertanian Kab. Banyuwangi., 2017). Adanya unggas peliharaan atau unggas liar disekitar sawah penggembalaan dapat berpotensi juga pada penularan virus penyakit ND. Keadaan ini yang memungkinkan itik dapat membawa dan menyebarkan virus penyakit ND melalui feses dari satu sawah ke sawah lainnya (Alexander, 2001). ND adalah penyakit zoonosis, meskipun bukan salah satu ancaman penting untuk kesehatan masyarakat. Infeksi pada manusia melalui paparan pada burung yang terinfeksi menyebabkan infeksi pada mata, konjungtivitis ringan dan gejala seperti influenza, hemoragi pada subkonjungtiva, sakit pada kepala dan demam, dan di kasus yang parah dapat mempengaruhi kerusakan yang kronis pada penglihatan (Chang., 1981; Swayne., 2003; Capua dan Alexander., 2009).

Desa Temuasri, Sempu, Banyuwangi merupakan desa dengan populasi ternak itik kurang lebih 5.000 ekor. Itik dilepaskan dan digembalakan ke sawah yang pasca panen oleh pemiliknya untuk mencari makan sendiri. Pengobatan pada itik yang sakit juga terbatas dengan obat tradisional yang dipercaya para peternak mampu mengobati itik yang sakit. Ternak itik yang dipelihara sama sekali tidak diberikan vaksin, sehingga itik semakin rentan dan mudah terinfeksi penyakit yang salah satunya yaitu penyakit ND (Dinas Pertanian Kab. Banyuwangi, 2017).

Menurut Saepulloh dan Darminto (2005), itik dapat berperan sebagai pembawa virus/carrier yang mana dapat ditularkan pada hewan unggas lain yang peka, untuk mengetahui adanya antibodi dari virus ND atau pernah terinfeksi virus ND pada itik maka salah satu cara yang perlu dilakukan deteksi antibodi terhadap virus ND pada itik di Desa Temuasri, Sempu, Banyuwangi.

\section{METODE PENELITIAN}

Pengambilan sampel darah di Desa Temuasri, Sempu, Banyuwangi, pemisahan sampel serum dilaksanakan di Laboratorium Instrumen Fakultas Kedokteran Hewan PSDKU Universitas Airlangga di Banyuwangi dan 
pengujian sampel serum dilaksanakan di Laboratorium Virologi Fakultas Kedokteran Hewan di Surabaya pada bulan Desember 2018 sampai Januari 2019. Penelitian ini merupakan kajian deskriptif lapang cross sectional. Besaran sampel yang didapat apabila besaran populasi tidak diketahui, maka besar sampel dihitung dengan rumus Lemeshow sejumlah 72 ekor itik.

Bahan yang digunakan adalah serum darah itik sebanyak 72 ekor yang diambil dari Desa Temuasri, Sempu, Banyuwangi, $\mathrm{NaCl}$ fisiologis, alkohol $70 \%$, eritrosit ayam $0,5 \%$, kapas, spuit 3 cc, microtube, microtip, tabung berisikan antikoagulan EDTA (Etylen Diamine Tetra Acetic Acid), Antigen ND (Terdaftar Deptan RI No. D. 0707142 VKC) yang diperoleh dari Pusvetma.

Alat yang digunakan adalah tabung venoject plain, rak tabung reaksi, sentrifuse, gelas beker $100 \mathrm{ml}$, microplate $\mathrm{V}$, micropipet ukuran $25 \mu \mathrm{l}$ dan $50 \mu$, labu erlenmeyer $100 \mathrm{ml}$, pipet hisap 1 $\mathrm{ml}$, pipet pasteur.

Pengambilan sampel dengan cara mengambil darah itik melalui vena brachialis menggunakan spuit 3 cc lalu masukkan ke dalam tabung venoject tanpa antikoagulan, darah dibiarkan beberapa saat dalam posisi miring hingga darah menggumpal dalam suhu kamar $\left(37^{\circ} \mathrm{C}\right)$ sampai keluar serumnya. Sampel darah dibawa ke Laboratorium Instrumen Fakultas Kedokteran Hewan PSDKU Universitas Airlangga di Banyuwangi menggunakan box berisi es gel. Bagi sampel yang belum keluar sampelnya dapat dilakukan sentrifuse dengan kecepatan $2500 \mathrm{rpm}$ selama 10 menit, kemudian serum dipisahkan dari gumpalan darah dan dimasukkan ke dalam tabung microtube, dan disimpan pada suhu $4^{\circ} \mathrm{C}$ sampai saat digunakan (Novitasari, 2016; Amanu dan Rohi., 2005). Setelah sampel lengkap letakkan pada box steroform berisi es gel dan dibawa ke Laboratorium Virologi Fakultas Kedokteran Hewan Universitas Airlangga di Surabaya untuk dilakukan pemeriksaan serologis uji HA dan uji HI.

Serum diinaktivasi dengan cara memanaskan diatas waterbath bersuhu $56^{\circ} \mathrm{C}$ selama 30 menit untuk menghilangkan hemaglutinin non spesifik dalam serum dengan proses inaktivasi (OIE.,
2012). Serum yang inaktiv dapat digunakan untuk uji $\mathrm{HI}$ atau disimpan pada freezer untuk penyimpanan lebih dari seminggu dan jika beberapa hari kemudian akan dipakai maka dapat disimpan di kulkas dengan suhu $4^{\circ} \mathrm{C}$.

Darah yang dipergunakan untuk pembuatan RBC diambil dari eritrosit ayam yang Spesific Pathogen Free (SPF), yang artinya ayam tersebut tidak memiliki titer antibodi dan umur ayam diatas 3 bulan. Pembuatannya dengan cara darah ayam diambil sebanyak $3 \mathrm{ml}$ melalui vena brachialis dan ditampung dalam tabung reaksi steril yang berisikan antikoagulan, kemudian dikocok perlahan dengan membentuk seperti angka delapan agar darah dan antikoagulan bercampur. $\mathrm{NaCl}$ fisiologis steril ditambahkan sebanyak $10 \mathrm{ml}$ kemudian disentrifugase selama 10 menit dengan kecepatan 3000 rpm, kemudian buang supernatannya, kemudian ulangi pencucian selama tiga kali. Sentrifugase dapat dihentikan ketika supernatan tampak jernih dan eritrosit terdapat di dasar tabung, buang supernatannya dan didapat RBC $100 \%$. Pembuatan suspensi eritrosit ayam $0.5 \%$ dengan cara eritrosit ayam $100 \%$ dibuat suspensi dengan kadar $0.5 \%$ dalam larutan $\mathrm{NaCl}$ fisiologis dengan menambahkan $99.5 \mathrm{ml}$ larutan $\mathrm{NaCl} 0.9 \%$ dan $0.5 \mathrm{ml}$ eritrosit ayam $100 \%$. Eritrosit ayam dengan konsentrasi $0.5 \%$ dapat digunakan langsung atau disimpan pada lemari es dengan suhu $4^{\circ} \mathrm{C}$ (Amanu dan Rohi, 2005).

Serum itik sebelum digunakan untuk uji HI, dilakukan treatment pada serum itik menggunakan eritrosit ayam untuk menghapus aglutinin non-spesifik, dimana kadang dapat menyebabkan aglutinasi non-spesifik pada sel darah merah ayam (Pedersen, 2008; OIE, 2012; WHO, 2002). Menurut OIE (2012), perbandingan serum dengan eritrosit ayam adalah 20:1, serum itik setelah diinkubasi dengan suhu $56^{\circ} \mathrm{C}$ selama 30 menit dapat langsung dilakukan treatment atau disimpan pada lemari es bersuhu $4^{\circ} \mathrm{C}$ untuk kemudian dilakukan treatment, dari setiap sampel serum itik sebanyak $200 \mu \mathrm{l}$ serum dimasukkan dalam microtube kemudian tambah dan campurkan dengan $10 \mu \mathrm{l}$ eritrosit ayam $100 \%$, kemudian disentrifugasi dengan kecepatan $2500 \mathrm{rpm}$ selama 10 menit 
untuk memisahkan serum dan eritrosit. Serum yang telah terpisah dari eritrosit dapat digunakan untuk uji $\mathrm{HI}$.

Uji HA merupakan uji serologis untuk mengetahui suatu virus memiliki kemampuan mengaglutinasi eritrosit dan juga untuk mengetahui titer virus dengan mengamati hasil dasar sumuran yang paling akhir dengan menunjukkan adanya hemaglutinasi positif (Selleck, 2007). Interpretasi hasil uji HA adalah hemaglutinasi terlihat jelas berupa lapisan eritrosit secara merata (difuse) pada dasar sumuran dan penjernihan dari cairan bagian atas tanpa terjadi pengendapan eritrosit berbentuk titik-titik ditengah sumuran. Dasar uji HI adalah reaksi ikatan antara antigen dengan antiserum dan eritrosit ayam $0.5 \%$, ketika antigen dan antiserum homolog dan tidak terjadi hemaglutinasi maka uji $\mathrm{HI}$ positif. Interpretasi $\mathrm{HI}$ adalah hambatan hemaglutinasi yang nampak dari pengendapan eritrosit pada dasar lubang microplate yang terlihat seperti bentuk titik. Kriteria dari hasil pemeriksaan menggunakan serum yang positif bila hasil uji HI menunjukan titer antibodi $\geq 24$ (OIE, 2012).

Data yang telah diperoleh dari hasil pemeriksaan uji HI ditabulasikan kemudian dianalisis secara deskriptif. Persentase hasil uji serologis positif dari keseluruhan sampel dapat dirumuskan sebagai berikut (Budiharta dan Suardana., 2007):

\section{$\%$ Seropositif ND=jumlah diperiksa positif $x 100 \%$ total sampel yang diperiksa}

\section{HASIL DAN PEMBAHASAN}

Kriteria dari hasil pemeriksaan sampel serum yang digunakan diperiksa dan dinyatakan positif apabila hasil uji HI menunjukan titer antibodi $\geq 2^{4}$ (OIE., 2012).

Petenakan itik di Desa Temuasri belum pernah dilakukan pemeriksaan antibodi terhadap virus ND ataupun vaksinasi ND pada itik peternak dan belum ada laporan atau data yang pasti terkait pernah atau tidaknya ternak itik terinfeksi virus ND (Dinas Peternakan Kabupaten Banyuwangi, 2018).
Hasil Uji HI (Tabel 1) menunjukan bahwa titer antibodi ND dari serum itik positif apabila menunjukkan titer $\geq 4 \log ^{2}$ (OIE, 2012). Hasil pada (Tabel 2) Uji HI adalah $2^{3}$ sebanyak 2 sampel, $2^{4}$ sebanyak 2 sampel, dan $2^{10}$ sebanyak 18 sampel dengan persentase hasil positif adalah $27.77 \%$. Titer antibodi dapat dipengaruhi oleh kesehatan itik, jumlah virus yang menginfeksi, dan perbedaan waktu infeksi (Purnamawati dan Sudarnika, 2008). Antibodi mulai dibentuk dan tampak dalam serum memerlukan waktu 6-10 hari (Rahmawati dkk., 2018), akan mencapai puncaknya pada 3-4 minggu, dan mengalami penurunannya kira-kira 3-4 bulan, ketika setelah 8-12 bulan antibodi sudah tidak terdeteksi (Amanu dan Rohi, 2005).

Menurut Yan et al (2011), infeksi terhadap ND di lapangan masih sering terjadi baik pada titer antibodi yang tinggi maupun titer antibodi yang rendah. Berdasarkan lokasi peternak 2 dibanding dengan peternak 1 dan 3 yang jauh dari pemukiman dan ternak unggas lain seperti ayam, entok dan burung liar dapat meminimalisir penyebaran VND. Adanya unggas lain dapat menyebabkan resiko penularan penyakit yang lebih tinggi, dalam prosedur biosekuriti dilakukan pemisahan hewan jenis unggas lain untuk mencegah terjadinya penularan penyakit (Grimes dan Jackson, 2015).

Menurut Retno dkk (2015), usaha saat ini yang dapat diterapkan untuk pengendalian ND adalah penerapan biosecurity dengan membatasi lalu lintas orang/kendaraan yang keluar/masuk kandang dilakukan pencelupan/penyemprotan dan penyikatan pada alas kaki, sanitasi air minum maupun tempat minum, sanitasi kandang maupun peralatan kandang, melakukan vaksinasi secara tepat jadwal vaksinasi serta kualitas vaksin dan metode thawing (peningkatan suhu yang bertahap), tata laksana vaksinasi yang sesuai serta kondisi kesehatan hewan yang akan divaksin, melakukan monitoring titer antibodi ND setelah vaksin pada 2-3 minggu (vaksin aktif) atau 3-4 minggu (vaksin inaktif) untuk mengetahui keberhasilan dari vaksinasi, pemberian vitamin untuk meningkatkan daya tahan tubuh hewan. 
Tabel 1. Hasil pemeriksaan serum darah pada itik terhadap titer ND dengan uji HI

\begin{tabular}{cccc}
\hline \multirow{2}{*}{ Lokasi Sampel } & \multirow{2}{*}{ Jumlah Sampel } & \multicolumn{2}{c}{ Hasil Peme riksaan } \\
\cline { 3 - 4 } & & Seropositif & Seronegatif \\
\hline Peternak 1 & 24 & $8(33.33 \%)$ & $16(66.67 \%)$ \\
Peternak 2 & 24 & $1(4.17 \%)$ & $23(95.83 \%)$ \\
Peternak 3 & 24 & $11(45.83 \%)$ & $13(54.17 \%)$ \\
\hline Total & $\mathbf{7 2}$ & $\mathbf{2 0}(\mathbf{2 7 . 7 7 \% )}$ & $\mathbf{5 2}(\mathbf{7 2 . 2 3 \% )}$ \\
\hline
\end{tabular}

Tabel 2. Sebaran titer antibodi positif ND

\begin{tabular}{cc}
\hline Titer Antibodi $\left(\mathbf{L o g}^{2}\right)$ & $\sum$ Sampel \\
\hline 3 & 2 \\
4 & 2 \\
10 & 18 \\
\hline Total & $\mathbf{2 2}$ \\
\hline
\end{tabular}

\section{KESIMPULAN}

Ditemukan dari 72 sampel serum itik di Desa Temuasri, Sempu, Banyuwangi 20 sampel serum itik $(27.77 \%)$ positif antibodi terhadap ND.

\section{UCAPAN TERIMA KASIH}

Peneliti mengucapkan terima kasih kepada Dinas Pertanian dan Dinas Penanaman Modal dan Pelayanan Terpadu Satu Pintu Kabupaten Banyuwangi, atas izin pengambilan sampel pada daerah tersebut.

\section{DAFTAR PUSTAKA}

Aldous, E.W., Alexander, D.J. 2001. Detection and differentiation of Newcastle disease virus (avian paramyxovirus type 1). Av. Pathol., 30(2), 117-128.

Alexander, D.J. 2001. Newcastle Disease: The Gordon Memorial Lecture. Br. Poult. Sci., 42, 5-22.

Alexander, D.J., Senne, D.A. 2008. Newcastle Disease and Other Avian Paramyxoviruses. In: Dufour-Zavala L., Swayne, D.E., Glisson, J.R., Jackwood, M.W., Pearson, J.E., Reed, W.M., Woolcock, P.R., editor. A Laboratory Manual for the Isolation, Identification and Characterization of Avian
Pathogens, Ed ke-4. Athens (US): American Association of Avian Pathologists, Athens GA. 135-141.

Amanu, S., Rohi, O.K. 2005. Studi Serologi Dengan Uji Hambatan Hemaglutinasi Terhadap Angsa Yang Dapat Bertindak Sebagai Pembawa Newcastle Disease di D. I. Yogyakarta. J. Sain Vet. 1, 8-12.

BPS. 2006. Produksi dan Konsumsi Daging dan Telur Tahun 2006.

BPS. 2008. Produksi dan Konsumsi Daging dan Telur Tahun Tahun 2008.

BPS. 2010. Produksi Daging Ternak, Konsumsi Daging dan Telur Tahun 2001-2010.

Budiharta, S., Suardana, I.W. 2007. Buku Ajar Epidemiologi \& Ekonomi Veteriner. Penerbit Universitas Udayana. Denpasar. Hal. 54-55.

CFSPH. 2008. Newcastle Disease. The Center for Food Security and Public Health, College of Veterinary Medicine, Lowa State University: Lowa. p1-8.

Capua, I., Alexander, D.J. 2009. Avian Influenza and Newcastle Disease. Springer-Verlag Italia. p19-26. 
Chang, P.W. 1981. Newcastle Disease. In: Beran GW (ed) CRC handbook series in zoonoses section B: Viral Zoonoses, Volume II. CRC, Baton Raton, p261-274.

Darminto, Ronohardjo, P. 1996. Karakterisasi Isolatisolat Virus Newcastle Disease Asal Wilayah Timur Indonesia. Pros. Temu Ilmiah Nasional Bidang Veteriner, 12-13 Maret 1996. Balitvet. Hal. 104-113.

Dinas Pertanian Kabupaten Banyuwangi, 2017. Rekap Kabupaten/Kota Populasi Ternak per Wilayah (Ekor).

Grimes, T., Jackson, C. 2015. Code of Practice for Biosecurity in the egg industry. Barton Australia; Rural Industries Research and Development Coorporation. Edisi II. p1-33

Miller, P.J., Decanini, E.L., Afonso, C.L. 2010. 'Newcastle Disease: Evolution of genotypes and the related diagnostic challenges, Infection, Genetics, and Evolution". Infection Gen. Evol., 10(1), 26-35.

Novitasari, A. 2016. Respon Imun Itik Bali Terhadap Pasca Vaksinasi Newcastle Disease. https://www.unud.ac.id/in/tugasakhir1209006001.html [18 Desember 2018]

OIE. 2012a. Newcastle Disease. www.oie.int

OIE. 2012b. Manual of standards for diagnostic tests and vaccines. Ed.7. Paris: Office Internationaldes Epizooties. p436-452.

OIE. 2012c. OIE Terrestrial Manual, Avian Influenza Chapter 2.3.4.

Pedersen, J.C. 2008. Hemagglutination inhibition test for avian influenza virus subtype identification and the detection and quantitation of serum antibodies to the avian influenza virus. Methods Mol. Biol., 436, 53-66.
Purnamawati, A., Sudarnika, E. 2008. Kajian Hasil Vaksinasi Avian Influenza pada Ayam Buras Rakyat di Kabupaten Tasikmalaya. Proceeding if AZWMC. Bogor: Hal. 281.

Rahmawati, A., Wijaya, N.S., Purnama, M.T.E., Rahmahani, J., Yudhana, A., Yunita, M.N. 2018. Pengaruh Ekstrak Kulit dan Jus Buah Delima Puth (Punica granatum L.) Terhadap Titer Antibodi Ayam Kampung Super yang Divaksin Newcastle Disease. J. Med. Vet., 1(3), 68-73.

Retno, F.D., Lestariningsih, C.L., Purwanto, B., Hartono, S. 2015. Penyakit-Penyakit Penting Pada Ayam. PT Medion. Bandung. Hal. 7080

Saepulloh, M., Darminto. 2005. Kajian Newcastle Disease Pada Itik Dan Upaya Pengendaliannya. Balai Penelitian Veteriner, Bogor dan Balai Pengkajian Teknologi Pertanian Jawa Timur. Malang. Hal. 84-94.

Selleck, P. 2007. Serological Tests for The Detection of Antibodies Againts Avian Influenza.CSIRO Australian Animal Health Laboratory, Geelong. Australia.

Swayne, D.E., King, D.J. 2003. "Avian Influenza and Newcastle Disease". JAVMA., 222(11), 1534-1540.

WHO. 2002. WHO mnual on animal influenza diagnosis and surveillance [internet]. www.who.int/csr/resources/publications/infl uenza/whocdscsrncs20025rev.pdf. [06 Februari 2019]

Yan, Y., Samal, S.K. 2008. Role of Intergenic Sequences in Newcastle Disease Virus RNA Transription and Pathogenesis. J. Virol., 82(3), 1323-1331. 